Maryna Michaluk

Biatystok

\title{
Tematyczna i słowotwórcza analiza grupy leksykalnej polityka zewnętrzna (na materiale języka rosyjskiego)
}

Słowa kluczowe: język rosyjski, językoznawstwo, leksyka polityczna, słowotwórstwo

Język jest jednym ze sposobów wyrażania działań, myśli i przekonań politycznych. Od połowy XX wieku w lingwistyce rosyjskiej w celu wskazania warstwy leksyki, której semantyka ma bezpośrednie lub pośrednie odniesienie do polityki i życia politycznego społeczeństwa, tradycyjnie stosuje się termin leksyka społeczno-polityczna (общественно-политическая лекси$\kappa a$, ОПЛ). Warto jednak zauważyć, że w celu określenia leksyki (a nie terminologii) ze znaczeniem politycznym w literaturze naukowej stosowane są także terminy leksyka socjalno-polityczna i leksyka polityczna. Pierwsze dwa terminy z wymienionych powyżej są synonimami, chociaż wyrażenie leksyka społeczno-polityczna można spotkać częściej niż leksyka socjalno-polityczna. Trudno jest mówić o różnicach pomiędzy leksyka społeczno-polityczna i leksyka polityczna, gdyż wybór słowa uwarunkowany jest przede wszystkim wolą i preferencjami autora. Niełatwo jest także wskazać różnice w znaczeniu wspomnianych terminów na podstawie analizy prac naukowych, w których się one pojawiają, ponieważ zazwyczaj autor wybiera jedno z pojęć i następnie konsekwentnie je stosuje. Ponadto różnice w interpretacji terminów nie są związane z wyborem konkretnego określenia, a uwarunkowane innymi przyczynami. Jednakże można zaobserwować, że w pracach poświęconych stosownej tematyce wyrażenie leksyka społeczno-polityczna pojawia się częściej niż leksyka polityczna.

Cechą wyróżniającą leksyki społeczno-politycznej w porównaniu z leksyką polityczną jest to, że pierwsza z nich zawiera w sobie takie słowa i zwro- 
ty, które oznaczają pojęcia związane z działalnością państwa i życiem politycznym społeczeństwa, ale nie mają bezpośredniego związku z realizacją władzy politycznej. Chodzi tu o leksemy, które reprezentują elementy składowe polityki ogólnopaństwowej (gospodarczej, socjalnej, wojskowej), funkcjonujące w sferze prawnej i administracyjnej. Każdą ze sfer życia społeczno-politycznego społeczeństwa charakteryzuje właściwa jej, wyspecjalizowana leksyka. Jako przykład można wskazać terminy, pochodzące z następujących dziedzin:

- gospodarka (np. рынок, приватизачия, монетаристская политика, консигначия);

- polityka militarna (np. война, горячая точка, силовик, моджахед);

- prawo (np. легитимность, правоотношения).

Względnie niezależny status leksyki politycznej tłumaczy się tym, że język polityki zawiera w sobie jednostki leksykalne właściwe dla innych sfer życia społecznego, np. z dziedziną prawa związane są terminy: конституиия, закон, президентское вето, пакт, ратификаиия; do sfery administracji należą leksemy: государственный чиновник, командно-административныи, вище-президентство. Natomiast w odniesieniu do trzech rodzajów władzy państwowej (ustawodawczej, wykonawczej i sądowniczej) w skład zasobu leksyki politycznej wchodzą słowa i wyrażenia, odnoszące się do dwóch pierwszych rodzajów władzy. Jest to uwarunkowane tym, że są one bezpośrednio związane z realizacją zarządzania państwem czy tė̇ polityki państwa, a władza sądownicza powiązana jest pośrednio. Jej funkcją jest realizacja prawa, co stanowi odrębną sferę, wymagającą oddzielnej analizy. Zatem słownictwo polityczne jest takim leksykalno-semantycznym podsystemem języka, którego elementy oznaczają pojęcia, zjawiska i procesy z dziedziny polityki, czyli odnoszące się do mechanizmów funkcjonowania władzy politycznej. Tak więc pod pojęciem leksyka polityczna rozumiemy ogół słów i wyrażeń, które zawierają komponent semantyczny 'mający odniesienie do polityki państwowej i międzynarodowej oraz życia politycznego społeczeństwa'. Zatem polityka jest określana jako działalność organów państwowych, sił społecznych i odrębnych osób, jest związana z dążeniem do władzy, jej zdobyciem, utrzymaniem i realizacją, a także z wpływem na władzę.

Problem klasyfikacji leksyki politycznej jest dość złożony i rozwiązywany przez badaczy lingwistów w różny sposób. Istnieje kilka klasyfikacji leksykonu politycznego, które różnią się od siebie. U podstaw każdego podziału znajduje się definicja leksyki politycznej i jej interpretacja, zmierzająca do określenia zakresu tego pojęcia. W związku z tym można stwierdzić istnienie związków przyczynowo-skutkowych pomiędzy zastosowanymi kryteriami 
klasyfikacji, a tym, jakie leksemy znajdą się w poszczególnych zdefiniowanych grupach.

Większość badaczy rosyjskich rozpatruje leksykę polityczną jako część leksyki społeczno-politycznej (А.С. Белая, Л.А. Жданова, А.Л. Голованевский, А.А. Карамова). Są badacze, którzy biorą pod uwagę tylko leksykę (О.И. Воробьева, Л.А. Жданова), oraz inni, analizujący tylko frazeologię (V.N. Coller, Э.В. Колесникова). Wybór klasyfikacji i jej ostateczny kształt zależy także od tego, którym aspektem opisu leksyki politycznej zainteresował się dany badacz. Na przykład, A.A. Karamova i V. Štefan wybrali do opisu leksykonu politycznego kryterium oceniajacce. A.A. Karamova oparła klasyfikację na zasadzie o charakterze nielingwistycznym i wybrała chronologiczny aspekt systematyzacji. Na tej podstawie wydzieliła następujące grupy leksyki społeczno-politycznej: polityka okresu radzieckiego, okresu do pierestrojki i okresu po pierestrojce [Карамова 2002]. Natomiast V. Štefan uwzględnił wyłącznie kryterium lingwistyczne i wyodrębnił dwie grupy leksyki politycznej. Pierwszą stanowią leksemy, których znaczenie polityczne określane jest przez kontekst. Do drugiej włączono leksemy zawierające w sobie komponent znaczeniowy związany z polityką [Штефан 1984].

W większości prac, poświęconych badaniom leksyki społeczno-politycznej, dominuje podział leksemów na grupy tematyczne. Jest to podyktowane konstrukcją i strukturą samego systemu politycznego.

Zasób leksyki politycznej można podzielić na dwa obszerne działy: polityka wewnętrzna i polityka zewnętrzna. Podział taki jest logiczny, gdyż dowolny kraj jako podmiot polityczny posiada swój własny ustrój polityczny, realizuje władzę wewnątrz swojego terytorium, a także wchodzi w relacje i stosunki polityczne z innymi państwami. W polityce wewnętrznej państwo organizuje i nadaje kształt władzy politycznej oraz określa zasady jej sprawowania i funkcjonowania, a ponadto narzuca formę systemu politycznego. W związku z tym oczywistym jest surowe podporządkowanie się podmiotów politycznych stojących niżej w hierarchii podmiotom będącym wyżej (są to stosunki polityczne o strukturze pionowej, określanej także jako wertykalna). Takie podporządkowanie wynika z definicji pojęcia władzy ${ }^{1}$.

\footnotetext{
1 Por.: na gruncie politologii: władza - 'zjawisko ogólnoludzkie i ogólnodziejowe, lecz wieloznaczne oraz przejawiające się w wielorako zróżnicowanych formach, jednak stanowiące wertykalną i asymetryczną relację międzyludzką, w której jedne podmioty są rządzące, a inne rządzone; przypadkiem szczególnie doniosłym dziejowo i brzemiennym w skutki, gdyż dotyczącym wszystkich zorganizowanych społeczności, jest w. polityczna [Bartyzel, Szlachta, Wielomski 2007, 439-440]; na gruncie socjologii: władza - 'relacje podporządkowania zachodzące między grupami społecznymi lub jednostkami, uprawniające jedną ze stron, rządzącą, do podejmowania decyzji w imieniu rządzonych oraz sprawowa-
} 
Natomiast polityka zewnętrzna ma inną specyfikę - na arenie międzynarodowej nie ma jednego centrum światowej polityki. W polityce zewnętrznej brak jest mechanizmu realizacji władzy z góry na dół, tak charakterystycznego dla polityki wewnętrznej, gdyż tu mamy do czynienia z samodzielnymi podmiotami - państwami, posiadającymi zasadniczo równe prawa. Cała polityka zewnętrzna - są to stosunki i relacje pomiędzy nimi (państwami), dlatego też centralne miejsce zajmują tutaj elementy językowe, oznaczające stosunki, relacje i działania polityczne.

Celem niniejszego opracowania jest prezentacja grupy tematycznej polityka zewnętrzna oraz analiza procesów słowotwórczych, a mianowicie derywatów prefiksalnych i skrótowców. Taki wybór został podyktowany innowacyjnością znaczeniową i aktywnością wyrazów tego pola semantycznego we współczesnym języku rosyjskim.

Materiał do analizy został wyekscerpowany z wybranych współczesnych słowników objaśniających języka rosyjskiego w oparciu o kryterium tematyczne ${ }^{2}$.

\section{Klasyfikacja tematyczna grupy leksykalnej polityka zewnętrzna}

Polityka zewnętrzna to, przede wszystkim, międzypaństwowa i międzynarodowa działalność polityczna i stosunki polityczne. Leksykę z zakresu polityki zewnętrznej można w określony sposób usystematyzować i podzielić na następujące grupy:

I. Słowa i wyrażenia nazywające najbardziej ogólne i kluczowe pojęcia związane $\mathrm{z}$ charakterystyką zewnętrznej działalności polityczпеј, пр.: большая политика, внешняя политика, внешнеполитический, глобально-политический, государство, (мировая, великая)

niu nad nimi kontroli' [Olechnicki, Załęcki 1997, 244-245]; w słownikach ogólnych języka polskiego: wladza - '1. zdolność jednostki lub grupy ludzi, zajmujących - z przyzwoleniem innych lub bez przyzwolenia - nadrzędną pozycję, do podporządkowywania zachowań innych ludzi swojej woli, swoim decyzjom i zamiarom' [Zgółkowa 2004, t. 45, 443; Szymczak 1996, t. 3, 681].

2 Н.3. Котелова (ред.), Новое в русской лексике. Словарные материаль - 1986, Санкт-Петербург 1996; Н.З. Котелова (ред.), Новое в русской лексике. Словарные материаль - 1987, Санкт-Петербург 1996; Е.А. Левашов (ред.), Новое в русской лексике. Словарные материаль - 1988, Санкт-Петербург 1996; Н.А. Николина, Е.А. Фролова, М.М. Литвинова, Словообразование современного русского языка, Москва 2005; Г.Н. Скляревская (ред.), Толковый словарь современного русского языка. Языковые изменения конца XX столетия, Москва 2001; Г.Н. Скляревская (ред.), Толковый словарь русского языка начала XXI века. Актуальная лексика, Москва 2006. 
держава, межгосударственный, международный, межпарламентский, межправительственныи, политика государства, сверхдержава, сверхполитика, суверенитет, суверенность, супердержава, супердержавность ${ }^{3}$.

W grupie tej znalazły się ogólne i podstawowe pojęcia, które służą do opisu areny międzynarodowej i jej podmiotów. Kluczowe są tu leksemy z przedrostkiem меж-, междy-, który wskazuje na pewien określony rodzaj relacji istniejącej pomiędzy rządami, państwami czy narodami. Osobny zbiór tworzą związki wyrazowe przymiotnika z rzeczownikiem, które opisują leksemy политика (внешняя, большая, великая, международная) і держава (великая, слаборазвитая, мировая).

II. Leksemy nazywające relacje międzypaństwowe związane $\mathrm{z}$ działalnością przedstawicielstw różnych państw: внешнеполитическое ведомство, встреча в верхах, дипломат, дипломатия, дипломатически, дипломатический, дипломатическое представительство, дипломатничать, дипломатические круги, консул, консульский, консульство, пакет дипломатических иничиатив, политико-дипломатический, полпред, полпредство, посол, посольский, посольство, промежуточная встреча на высшем уровне і in.

W grupie tej znalazły się nazwy osób (дипломат, консул, посол) i instytucji (ведомство, консульство, полпредство, посольство) огаz wyrażenia, w których te nazwy występują.

III. Słowa i wyrażenia nazywające stosunki międzypaństwowe związane z działaniami państw. W obrębie tej grupy można wyróżnić następujące podgrupy:

a) leksemy dotyczące kwestii połączenia (przyłączenia) lub oznaczające rozdzielenie (odłączenie). Pojawiły się tutaj leksemy i wyrażenia, które oznaczają międzypaństwowe organizacje polityczne i charakteryzują ich działalność: leksemy, które służą do opisu działań i funkcjonowania organizacji międzynarodowych, nazwy tych organizacji oraz leksemy, w których zawarte jest znaczenie połączenia lub rozdzielenia, np. альянс, блок (jako 'объединение го-

\footnotetext{
3 межгосударственный 'относящийся к деятельности различных государств и их взаимоотошениям, осуществляемым различными государствами' [TСРЯХХІ, 577]; межпарламентский '1. Существующий, происходящий между парламентами разных государств; 2. Состоящий из представителей парламентов разных государств' [TСРЯХХІ, 578]; межправительственный '1. Существующий, установленный между правительствами разных стран; 2. Состоящий из представителей правительств разных государств' [ТСРЯХХІ, 579].
} 
сударств'), евроамериканская семья, Европейская ассамблея, Европейский парламент (Европарламент), Европейский со$ю 3$ (Евросоюз), коаличионность, коаличионный, коаличия (јаkо 'союз, объединение государств'), консолидироваться, конференция, межсоюзный, НАТО, натовский, натомания, Организаиия Объединенных Наций (ООН), Парламентская ассамблея (Межпарламентская ассамблея, ассамблея), политическая интеграчия, проатлантический, проиракский, пропалестинский, саммит, сблокироваться, североатлантист, сепаратизм, сепаратист, Совет Европьи (CE), союз, унитаризм, унитарныци i in.

b) leksemy w znaczeniu 'podpisanie, przyjęcie lub zerwanie porozumień', nр.: денонсачия, конвенционный, конвенция, консенсус, международный договор, пакт, ратификационный, ратификаиия, ратифичировать(ся) itp.

c) leksemy odzwierciedlające problemy konfliktów międzypaństwowych, wojen i pokoju, np.: anapтеuд, ближневосточный, ближневосточное мирное урегулирование, гонка вооружений, деколонизачия, ирангейтовский, колониалистский, колониальный, международная безопасность, миротворчество, наращивание военного присутствия, нейтралитет, (нео)колониализм, (нео)колониалист, (нео)колонизатор, (нео)колония, полуколониальный, переговорный прочесс, примирение, примиренчество, примирительный, радикализм, радикальничать, радикально, радикальность, радикальный, разрядка, расизм, расист, сионизм, сионист(ка), сионистский, террор, ультиматум, хунта, «холодная война», шовинизм, экстремизм, экстремист, ЮАРгейт i in.

Trzecia podgrupa zawiera leksykę związaną z opisem konfliktów, wojen oraz pokoju. Znalazły się tu nazwy poglądów, ruchów politycznych, nazwy stanu wzajemnych relacji (np. неümpaлитет, переговорный прочесс, ультиматум).

W słowniku polityki zewnętrznej znajdują się też pojedyncze leksemy, które nie wchodzą w skład wymienionych powyżej grup tematycznych, np.: деидеологизачия межгосударственных (международных) отношений (sfera ideologii), геополитика, геополитический (dziedzina polityki zewnętrznej), государство «третьего мира» (określenie kraju, który osiągnął swoją niezależność polityczną), Большая двойка ('о СССР и США - государствах-лидерах' [НвРЛ-86, 38]), «Большая семерка» ('о высших руководителях семи наиболее развитых в экономическом отноше- 
нии стран' [ТСРЯ, 88]), napumem (jako zasada w zakresie polityki zewnętrznej) i in.

\section{Analiza wybranych procesów słowotwórczych w ramach grupy tematycznej polityka zewnętrzna- derywaty prefiksalne i skrótowce}

W słowotwórstwie końca XX wieku zachodziły procesy, które były charakterystyczne dla języka rosyjskiego jako całości: wzrost znaczenia autorskiego „ja”, przemieszanie elementów typowych dla różnych stylów (języka mówionego, mowy potocznej czy żargonu) w ramach jednej wypowiedzi i in. Język stał się bardziej ekspresyjny dzięki pojawiającym się okazjonalizmom, realizującym także funkcję nominacji, a oswobodzenie od różnorakich ograniczeń i zburzenie sowieckich stereotypów myślenia sprzyjało swoistemu wyzwoleniu języka i aktywizacji indywidualnego słowotwórstwa. Procesy, które zachodziły w zmieniającej się rzeczywistości, wymagały nowych nazw i w związku z tym aktywizowały określone elementy systemu słowotwórczego języka. Należy zauważyć, że słowotwórstwo końca XX i początku XXI wieku miało jasno wyrażony antropocentryczny charakter, o czym świadczy fakt, że znaczące miejsce wśród nowych słów zajmowały nazwy osób, także jako słowa bazowe. Pod koniec XX wieku bardzo produktywnie przebiegało tworzenie rzeczowników na drodze prefiksacji. Popularne były te przedrostki, które miały semantykę istotną z punktu widzenia społecznego i kulturowego. Znalazły się wśród nich prefiksy, które tworzyły rzeczowniki, odzwierciedlające następujące typy relacji: 1. relacje czasowe (nocm-, nocлe-), relacje zniszczenia, odrzucenia, przeciwstawienia (де-, анти-, контр-, раз-), relacje wsparcia (npo-), relacje nieprawdziwości, kłamstwa (псевдо-, квази-), relacje intensywności, wysokiego stopnia czegoś (cynep-, сверx-) i in. Ponadto, do grupy ekspresyjnych środków językowych weszła abrewiacja [Земская 2000, 138-139].

Charakterystyczną cechą współczesnego rosyjskiego słowotwórstwa jest tzw. „рост именной префиксации” [Земская 1996; Николина 2005], tj. tworzenie nowych nominacji poprzez dodanie przedrostka. Do grupy prefiksów, najczęściej biorących udział w tworzeniu nowych słów w języku polityki, należą: анти-, де-, контр-, лже-, нео-, пост-, после-, пред-, до-, nро-, сверx-, псевдо-, супер-, ультра-. Wśród nich możemy wyodrębnić prefiksy, które wcześniej także wykazywały wysoką produktywność ( суnер-, сверx-) oraz prefiksy, które były mało produktywne [Земская 2000, 110-118]. Aktywizacja tych afiksów często była uwarunkowana przyczynami pozalingwistycznymi. 
Przy pomocy środków językowych wyrażana była także ocena sytuacji politycznej w Rosji w latach 90. XX wieku. Społeczeństwo widziało, że to, co dzieje się w kraju, nie jest adekwatne do tego, co dziać się powinno. Znacząco wzrosła częstotliwość zastosowania prefiksów, wyrażających znaczenie odrzucenia, negowania działań przeciwnych, zniszczenia rezultatów czyichś działań. Odzwierciedleniem takiego stosunku do otaczającej rzeczywistości było użycie prefiksów анти-, контр-, лже-, псевдо- ${ }^{4}$, пр.: лжекоаличия, лжеполитик, антигорбачевчь, антипутин, псевдодемократ, псевдопарламент, псевдодемократический, псевдосуверенизачия, контрперестройка, контрреформа, контрэлита, контртеррористический. Derywaty z wymienionymi wyżej prefiksami odzwierciedlają istniejące we współczesnej Rosji antagonizmy.

Prefiks aнтu-, w odróżnieniu od prefiksów лже- i псевдо-, wyraża znaczenie braku zgody i akceptacji oraz całkowitej negacji treści, która zawarta jest w podstawie. Dość często w leksemach, utworzonych przy pomocy tego afiksu, zawarte jest znaczenie wrogości skierowanej przeciw komuś lub czemuś, np.: антигорбачевский - 'враждебный президенту CCCP М.С. Горбачеву; направленный против проводившейся им политики' [ТСРЯХХІ, 69]; антидемократ - 'противник демократии, демократов' [ТСРЯХХІ, 69]; антипутинский (противник В.В. Путина) itp.

N.A. Nikolina zauważa, że „к группе высокопродуктивных морфем относятся также приставки, выражающие отношение ложности, интенсивности (квази-, псевдо-)" [2005, 127], пр.: квазипартии, квазитоталитаризм, квазисочиалистический, псевдодемократ, псевдопатриот, псевдороссияне, псевдосуверенитет i in.

Nominacje z przedrostkiem псевдо- zawierają nie tylko subiektywną ocenę osób czy zjawisk, ale także charakteryzują stan podmiotu, nр.: псевдодемократ ('ненастоящий, мнимый демократ'), псевдолиберализм ('ненастоящий, мнимый либерализм'), псевдонационализм ('ненастоящий, мнимый национализм'), псевдооппозичия ('ненастоящая, мнимая оппозиция'), псевдосоциализм ('ненастоящий, мнимый социализм').

Dla procesów nominacji lat 80. i 90. XX wieku charakterystyczny jest prefiks $\partial e-$. Oznacza on brak, zmianę, odrzucenie czegoś, nazywa procesy likwidacji tego, co kształtowało realia minionej epoki (socjalizmu), a sło-

4 aнmu- (anty-) - wyraża przeciwieństwo cechy oraz tworzy 'nazwy kierunków czy postaw przeciwstawiających się tym, które oznaczają tematy słowotwórcze' [Grzegorczykowa 1998, 432, 451]; контр- (kontr-) - wyraża 'znaczenie walki, przeciwstawienia się temu, co oznacza postawa' [Grzegorczykowa 1998, 432, 451]. 
wa utworzone z jego pomocą w większości przypadków prezentują odrzucenie starego systemu politycznego, nр.: деидеологизаиия ('устранение из различных сфер общественной жизни преобладающего влияния одной определенной идеологии' [ТСРЯХХІ, 283]), дебюрократизаиия, дефедерализачия, департизачия, деполитизачия, деколлективизачия, декоммунизачия, демодернизачия, демонополизачия, денационализачия, деноменклатуризачия, десоветизачия, десталинизачия, децентрализачия i in.

Prefiksy nocлe- i nocm- wnoszą do treści tworzonych przez nie słów znaczenie pokonania pewnej granicy czasowej, nadejścia nowego momentu historycznego, nр.: послепутчевыи ('относящийся ко времени после путча (попытки реакционного переворота просоветского толка 19-21 августа 1991 года в СССР)' ТСРЯХХІ, 758), послеавгустовский ('относящийся ко времени после реакционного путча просоветского толка, произошедшего 19-21 августа 1991 года в СССР)' ТСРЯХХІ, 758), послекризисный ('относящийся ко времени после финансового кризиса в России, произошедшего 17 августа 1998 г.' ТСРЯХХІ, 758), послеоктябрьский (dotyczący okresu po rewolucji w październiku 1917 roku), noслеоттепельньй ('относящийся ко времени конца 60-х - 70-х гг. ХХ в. - после так называемой «оттепели»' ТСРЯХХІ, 758), послесталинский (synonim do постсталинский), послереферендумный; посткоммунист, посткризисный (synonim do послекризисныи), постсоветский (sуnоnim do послесоветский), постперестроечньий ('относящийся ко времени после периода перестройки в бывшем Советском Союзе, после подавления августовского путча распада СССР в 1991 г.' ТСРЯХХІ, 763), nостперестройщик, постсоциализм ('система экономических, политических и социальных отношений, сложившаяся на территории бывшего СССР после распада социалистической системы' ТСРЯХХІ, 765), постсоциалистический, посттоталитарный ('относящийся ко времени после разрушения тоталитаризма бывшего СССР' ТСРЯХХХ, 765), постъельиинский ('относящийся ко времени после завершения президентского правления Б.Н. Ельцина' ТСРЯХХІ, 765).

Znaczną aktywność przejawiały także prefiksy nped- i дo- z ogólnym znaczeniem granicy czasowej: предвыборный, предперестроечный, предкризисньй, предынаугурачионный; доперестроечньй, доапрельский ('относящийся к периоду до апрельского Пленума ЦК КПСС 1985 г., провозгласившего курс на перестройку, предшествующий ему' [НвРЛ-88, 102]), додефолтовский ('относящийся ко времени до дефолта 1998 года' ТСРЯХХІ, 320), докризисный ('относящийся ко времени до финансового кризиса в России 17 августа 1998 года' ТСРЯХХІ, 320), 
дореформенный ('относящийся ко времени, предшествующему коренной реформе всех сфер хизни в СССР (перестройке)' ТСРЯХХІ, 324).

Przy pomocy przedrostka npo- tworzono słowa ze znaczeniem 'w czyichś interesach, na czyjąś korzyść', 'zwolennik kogoś lub czegoś'. Aktywizacja tego prefiksu związana jest z czynnikami socjalnymi. Można powiedzieć, że zachodziła swoista deideologizacja słów z prefiksem npo-, które do pierestrojki zawierały negatywną ocenę ideologiczną i były bardzo popularne w propagandzie sowieckiej (np.: прокитайский, проНАТОвский itp.). W okresie po pierestrojce lat 90 . XX w. omawiany przedrostek utrzymał swoją aktywność słowotwórczą (np.: проельиинский, прозападный, прокоммунист, прокоммунистический, прокремлевский, пролужковский, промонархический, просочиалистический, проправительственный, пропрезидентский, пропутинский, пророссийский itp.).

Dążenie do znalezienia paraleli pomiędzy współczesnością i przeszłością doprowadziło do powstania wielu leksemów z afiksem нео- (z gr. neós 'nowy'), odpowiadających pod względem znaczenia wyrazowi новый, пр.: необольшевизм ('течение в идеологии и политике, развивающееся в русле коммунистического движения и являющееся идейным продолжением большевизма' ТСРЯХХХ, 652), необольшевистский ('относящийся к необольшевизму' ТСРЯХХІ, 652), неокапитализм ('течение в идеологии и политике, направленное на возрождение идей сталинизма' ТСРЯХХІ, 653), неокоммунизм ('течение в идеологии и политике, развивающее и продолжающее идеи коммунизма' ТСРЯХХХI, 652), неокоммунист ('представитель неокоммунизма' ТСРЯХХХ, 652), неокоммунистический ('относящийся к неокоммунизму' ТСРЯХХІ, 652), неосталинизм ('течение в идеологии и политике, направленное на возрождение идей сталинизма' ТСРЯХХІ, 653), неосталинист ('сторонник неосталинизма' ТСРЯХХХ, 653), неосталинистский ('относящийся к неосталинизму' ТСРЯХХХI, 653), неототалитаризм ('течение в идеологии и политике, направленное на возрождение тоталитаризма' ТСРЯХХІ, 653), неототалитарный ('развивающийся в духе тоталитаризма, возраждающий идеи и методы тоталитаризма' ТСРЯХХІ, 653). W obecnej publicystyce słowa te posiadają najczęściej negatywne zabarwienie.

Znaczną produktywność wykazywały synonimiczne prefiksy cверxi cynep-, oznaczające wysoki stopień przejawiania się danej cechy, dominację, nadmiar, intensywność występowania, np.: суперпрезидент, суперлоббист, сверхминистерство, сверхимперия. Należy dodać, że prefiks сверхjest rdzennie rosyjskim elementem, a cynep- jego obcojęzycznym ekwiwalentem (сверхдержава - супердержава, сверхпарламент - суперпарла- 
мент). Wysoką frekwencję słów z wymienionymi prefiksami warunkują dwie przyczyny. Pierwszą z nich jest tendencja do wyrażania ekspresji, podkreślenia emocjonalnośsi wypowiedzi, np.: przymiotniki cynеросторожный $\partial u$ пломат; сверхценная идея, сверхмилитаризованная экономика, сверхактивная жизнь; rzeczowniki супердержава, суперполицейский, супершпион, суперреформатор, a druga - potrzeba oznaczania zjawisk, związanych z procesem naukowo-technicznym, wyrażonych głównie przez rzeczowniki z cynер-, nр.: супертуннель, супердвигатель, супердорога, суперсборная. Druga z przyczyn nie ma odniesienia do języka polityki, ale ilustruje produktywność sufiksów i przebieg procesów słowotwórczych.

Funkcję elementu wzmacniającego znaczenie spełnia prefiks yльтра-, wyrażający wyższy stopień przejawiania się cechy i wnoszący znaczenie 'ponad', nр.: ультрапатриотический ('относящийся к крайнему шовинизму' ТСРЯ, 799), ультралиберальный ('относящийся к крайнему либерализму, крайним проявлениям либерализма' ТСРЯХХІ, 1009), ультралиберал ('сторонник крайнего либерализма и крайних проявлений либерализации' ТСРЯХХІ, 1008), ультраперестроечный ('провозглашающий принятие крайних мер в политике перестройки' НвРЛ-87, 291), ультранацтонализм ('национализм в крайних, реакционных формах' ТСРЯХХІ, 1009), ультранационалист ('сторонник ультранационализма' ТСРЯХXI, 1009).

Warunki ekstralingwistyczne (m.in. zmiana składu organów władzy, przeobrażenia struktur państwowych) uaktywniły przedrostek экc-, tworzący słowa złożone i wnoszący znaczenie 'były' ('бывший'), nр.: экc-губернатор, экс-депутат, экс-министр, экс-мэр, экс-политик, экс-президент, экс-премьер, экс-советский, экс-спикер, экс-супердержава. Zastępców osób, zajmujących kluczowe stanowiska w państwie zaczęto nazywać z pomocą elementu вuцe-, mającego pochodzenie łacińskie, nр.: вище-губернатор, вище-премьер, виче-мэр itp. Prefiks экс- łączy się nie tylko ze słowami, oznaczającymi tytuły i stanowiska, ale również z leksemami, które nazywają osoby według zawodów, rodzaju wykonywanej działalności, miejsca zamieszkania, charakterystyk psychofizycznych, пр.: экс-бизнесмен, экс-владелеи «Евросети», экс-пилот, экс-музыкант, экс-суперзвезда itp. Nie wszystkie z wymienionych przykładów pochodzą $\mathrm{z}$ języka polityki, ale zostały przywołane $\mathrm{w}$ celu zaprezentowania łączliwości omawianego prefiksu.

Warto zauważyć, że produktywne współcześnie prefiksy charakteryzują się szeroką łączliwością $\mathrm{z}$ różnymi tematami. Ma to miejsce także w zakresie leksyki politycznej. Jako formy wyjściowe mogą występować nazwy własne (np. анти-Ельиин, мега-Европа, псевдо-Россия, 
экс-Черномырдин, экс-Борис Березовский), skrótowce (np. анти-НАТО, анти-ГАИ, супер-НАТО, экс-СССР), liczebniki (np. экс-первая леди Франиии, движение "Анти-2004"), całe wyrażenia (np. экс-королева Майдана, экс-первая леди Америки).

$$
* * *
$$

Leksemy należące do grupy leksykalnej polityka zewnętrzna powstawały z wykorzystaniem różnych prefiksów. Należy jednak zauważyć, że nie wszystkie omówione wyżej przedrostki znalazły w niej swoje odzwierciedlenie.

Dokonana analiza wykazała udział wyrazów z następującymi prefiksami:

- про- (w znaczeniu 'zwolennik, w czyich interesach'): проатлантический, проиракский, пропалестинский, проевропейский;

- нео- ('nоwy'): неоколониализм, неоколониалист, неоколонизатор, неоколния;

- сверx-, сynep- (oznaczające wysoki stopień przejawiania danej cechy, nadmiar, intensywność, dominację): супердержава, супердержавность, сверхполитика, сверхдержава;

- де- ('brak, zmiana, odrzucenie, likwidacja'): деколонизация;

- меж- ('pomiędzy'): межсосударственный, межправительственный, межсоюзный, межпарламентский, международный.

W omawianej grupie leksemów zwraca uwagę brak jednostek z prefiksami oznaczającymi 'odrzucenie', 'negację działań przeciwnych' (анти-, контр-, лже-, псевдо-). Nie występują tu także wyrazy z przedrostkami nосле- i nocm- (oznaczającymi 'pokonanie granicy czasowej', 'nowy moment historyczny'). Leksemy z tymi prefiksami tworzą obszerny zbiór w grupie leksykalnej polityka wewnętrzna, która nie jest przedmiotem analizy w niniejszym artykule. Ponadto odnotowano brak leksemów z prefiksami ультра- (w znaczeniu 'ponad'), пред- oraz до- w znaczeniu 'określenia granicy czasowej'.

W analizowanej grupie tematycznej zwraca uwage niewielka grupa skrótowców ${ }^{5}$ : skrótowce głoskowe, np. НАТО, ООН (Северо-Атлантический Альянс, Организаџия Объединенньх Наций); literowe, np. CE, EC

5 Skrótowce kondensują przede wszystkim wielowyrazowe nazwy różnych instytucji. Można wyróżnić skrótowce literowe (literowce - złożone z pierwszych liter wyrazów skracanego wyrażenia, np. $N B P$ ), grupowe (sylabowe) czyli grupowce (sylabowce) - złożone z grup głoskowych wybranych z wyrazów, wchodzących w skład skracanego wyrażenia, np. Polfa), głoskowe (głoskowce - utworzone z początkowych głosek skracanego wyrażenia, np. NATO) czy też mieszane, będące kombinacją początkowych sylab i głosek 
(Совет Европьи, Европейский Союз); sylabowe, nр. полпред, полпредство (полномочный представитель, полномочное представительство); złożeniowe, np. Европарламент, Евросоюз (Европейский парламент, Европейский союз).

W podsumowaniu warto podkreślić, że klasyfikacja słownictwa pola semantycznego polityka zewnętrzna pozwoliła wyodrębnić następujące grupy tematyczne:

1. Słowa i wyrażenia, nazywające najbardziej ogólne i kluczowe pojęcia związane z charakterystyką zewnętrznej działalności politycznej.

2. Określenia stosunków międzypaństwowych związanych z działalnością przedstawicielstw różnych państw.

3. Nominacje dotyczące stosunków międzypaństwowych związanych z działaniami państw. W obrębie tej grupy można wyróżnić następujące podgrupy:

a) leksemy, wyrażające kwestie połączenia (przyłączenia) lub oznaczające rozdzielenie (odłączenie); chodzi tu głównie o międzypaństwowe organizacje polityczne i charakterystykę ich działalności;

b) leksemy w znaczeniu 'podpisanie, przyjęcie lub zerwanie porozumień';

c) leksemy, odzwierciedlające problemy konfliktów międzypaństwowych, wojen i pokoju.

Podział ten oparty jest na podstawowej charakterystyce polityki zewnętrznej, i odzwierciedla równorzędność relacji (a nie podporządkowania) oraz stosunków pomiędzy podmiotami. Stąd też centralne miejsce zajmują tu elementy językowe opisujące stosunki, relacje i działania polityczne.

Analiza słowotwórcza pokazała niewielką różnorodność w zakresie prefiksacji, gdyż odnotowano leksemy derywowane przy pomocy przedrostków про-, нео-, меж-, де-, сверх-, супер-, i brak leksemów z prefiksami анти-, контр-, лже-, псевдо-, после-і пост- oraz ультра-, пред- і до-.

\section{Wykaz skrótów}

НвРЛ-86 - Новое в русской лексике. Словарные материаль - 1986, под ред. Н.З. Котеловой, Санкт-Петербург 1996.

(np. $C B O S$ ) lub złożeniowe (w ich skład wchodzi wyraz określany i część wyrazu określającego, np. Investbank) [rodzaje skrótowców za Stownikiem poprawnej polszczyzny, pod red. W. Doroszewskiego, Warszawa 1997, s. 695]. 
НвРЛ-87 - Новое в русской лексике. Словарнье материаль - 1987, под ред. Н.З. Котеловой, Санкт-Петербург 1996.

НвРЛ-88 - Новое в русской лексике. Словарнье материаль - 1988, под ред. Е.А. Левашова, Санкт-Петербург 1996.

ТСРЯ - Толковый словарь современного русского языка. Языковые изменения конца $X X$ столетия, под ред. Г.Н. Скляревской, Москва 2001.

ТСРЯХХІ - Толковый словарь русского языка начала ХХІ века. Актуальная лексика, под ред. Г.Н. Скляревской, Москва 2006.

\section{Literatura}

Bartyzel J., Szlachta B., Wielomski A., 2007, Encyklopedia polityczna, Myśl polityczna: główne pojęcia, doktryny i formy ustroju, t. 1, Radom.

Doroszewski W. (red.), 1997, Stownik poprawnej polszczyzny, Warszawa.

Grzegorczykowa R., Laskowski R., Wróbel H., 1998, Gramatyka współczesnego języka polskiego. Morfologia, Warszawa.

Olechnicki K., Załęcki P., 1997, Słownik socjologiczny, Torun.

Szymczak M. (red.), 1996, Stownik jezzyka polskiego PWN, R-Z, t. 3, Warszawa.

Zgółkowa H., 2004, Praktyczny słownik współczesnej polszczyzny, t. 45, Poznań.

Земская Е.А., 1996, Активнье прочессы современного словопроизводства, [в:] Русский язык кониа ХХ столетия, Москва, с. 90-140.

Земская Е.А., 2000, Литературная норма и неузуальное словообразование, [в:] Современный руский язык: Система - Норма - Узус, Москва, c. $207-253$.

Карамова А.А., 2002, Оченочная общественно-политическая лексика и фразеология современного русского языка (2-я половина XX века), Автореф. дис. канд. филол. наук, Уфа.

Котелова Н.3. (ред.), 1996, Новое в русской лексике. Словарные материаль 1986, Санкт-Петербург.

Котелова Н.3. (ред.), 1996, Новое в русской лексике. Словарнье материаль 1987, Санкт-Петербург.

Левашов Е.А. (ред.), 1996, Новое в русской лексике. Словарные материаль 1988, Санкт-Петербург.

Николина Н.А., Фролова Е.А., Литвинова М.М., 2005, Словообразование современного русского языка, Москва.

Скляревская Г.Н. (ред.), 2001, Толковый словарь современного русского языка. Языковые изменения конца XX столетия, Москва. 
Скляревская Г.Н. (ред.), 2006, Толковый словарь русского языка начала ХХІ века. Актуальная лексика, Москва.

Штефан В., 1984, Ингерентная и агрегентная экспрессивно-оченочная политическая лексика и фразеология современного русского языка (на материале газетье «Правда»), Автореф. дис. канд. филол. наук, Ростов-на-Дону.

\author{
THEMATIC AND FORMATIVE ANALYSIS OF THE LEXICAL GROUP \\ EXTERNAL POLICY (BASED ON THE RUSSIAN LEXICAL MATERIAL)
}

S U M M A R Y

Political lexis may be divided into two vast divisions: internal policy and external policy. A distinctive quality of foreign policy is the fact that in the international arena exists no one center and the whole policy in point is constituted by relations between states. Therefore the central place is in this case occupied by linguistic elements denominating just political relations and actions.

The article is an attempt at a thematic and formative characteristics of the lexical group EXTERNAL POLICY.

The first part of the article is thematic classification. On its basis three groups of lexemes have been distinguished. The first one contains general and basic terms which are indispensable to describe the international arena and its entities (е.g. внешняя политика, сверхполитика). The second group consists of expressions for international relations connected with the activity of representations of various states (е.g. дипломат, консул, полпред). The third group includes names of international relations connected with activities of states (integration/separation, signing/cancelling agreements, conflicts between states).

The second part of the article is an analysis of selected formative processes within the group EXTERNAL POLICY. It discusses the process of prefixation and the analysis demonstrated inconsiderable variety in this field, since the lexemes noted had only a few prefixes (nро-, нео-, меж-, де-, сверх-, супер-). No expressions with the prefixes анти-, контр-, лже-, псевдо-, после, пост-, ультра-, пред- and do- have not been noted.

Maryna Michaluk e-mail: msiemieniuk@wp.pl 